\title{
LA OBRA TOTAL DE RAÚL ZURITA: LAS MÚLTIPLES POSIBILIDADES DEL PAISAJE*
}

\author{
RAÚL ZURITA'S TOTAL WORK OF ART: \\ THE MULTIPLE POSSIBILITIES OF LANDSCAPE
}

\author{
PAULA MIRANDA ${ }^{\star *}$, RAFAEL RUBIO ${ }^{\star * *}$
}

Resumen: Este artículo estudia la obra del poeta chileno Raúl Zurita entendiéndola como una obra total, distinguiendo dos etapas fundamentales y prestándole especial atención a la utilización del paisaje como método que le permite al poeta inscribirescribir los signos del horror, la desesperanza y la compasión humanas, en la palabra y en el espacio físico. Los dos momentos diferenciados son: uno que va desde la herida en la mejilla (1975) hasta La vida nueva (1994), y otro que va desde INRI (2003) hasta Zurita (2011). Se analiza el tema de manera más detenida en sus libros fundamentales, aunque siempre en perspectiva comparativa (Purgatorio, Anteparaíso, Canto a su amor desaparecido, La vida nueva, INRI, Los países muertos y Zurita). Se analizan también sus diversas intervenciones corporales y geográficas (escritura material) y su sentido, tanto poético como icónico-textual, al interior de los diversos poemarios y del proyecto total. Para el estudio se incorporan análisis textuales y contextuales, entrevistas al autor y discusiones bibliográficas.

PALABRAS ClAVE: Raúl Zurita, paisaje, escritura material, obra total.

Aвstract: This article studies the Chilean poet Raúl Zurita's poetry as a total work of art divided into to two fundamental stages, while placing a particular focus on the use of landscape as a method that allows the poet to inscribe the signs of horror, desperation, and compassion on the page and in the physical environment. The first stage analyzed in this article is delimited by Zurita's self-inflicted facial wound (1975) and the publication of La vida nueva (1994), while the second begins with INRI (2003) and concludes with Zurita (2011). While a comparative approach to Zurita's work is em-

\footnotetext{
* Este artículo fue posible gracias a la realización del Proyecto Regular Fondecyt No 1141152 (20132016), "Países y paisajes en la poesía de Raúl Zurita: diálogos, mutaciones y desapariciones (19712013)", cuya investigadora responsable es Paula Miranda Herrera y cuyo coinvestigador es Rafael Rubio. Parte de su desarrollo se inscribe también en el Proyecto Conicyt/Fondap 15110006, creación del CIIR, en el que Paula Miranda es Investigadora Asociada para este periodo.

** Doctora en Literatura. Académica de la Facultad de Letras UC, Santiago, Chile. Correo electrónico: pmirandh@uc.cl.

*** Doctor en Literatura. Poeta y académico de la Facultad de Letras UC, Santiago, Chile. Correo electrónico: rirubio@uc.cl.
} 
ployed, the analysis will focus on his most important books (Purgatorio, Anteparaíso, Canto a su amor desaparecido, La vida nueva, INRI, Los países muertos y Zurita). This article likewise analyzes Zurita's various corporal and geographical interventions and their meaning, both poetic and iconic-textual, within his diverse poetry collections and within his project as a whole. This study makes use of textual and historical analysis, as well as interviews with the author and critical studies.

KEYWORDS: Raúl Zurita, landscape, material writing, total work of art.

Recibido: 30.06.17. Aceptado: 17.11.17.

\section{PROYECCIÓN Y SENTIDO DE LOS PAISAJES}

EN LA OBRA DE ZURITA

$\mathrm{M}$ Ás QUE PREGUNTARSE por las características del paisaje en Raúl Zurita, en tanto lugar, nos ha preocupado preguntarnos cuál es la función de este al interior de su sistema poético, el que se compone de sus libros, sus intervenciones en el espacio físico y corporal, los iconotextos visuales y fotográficos de esas intervenciones y también su propia vida. Además, considerando el contexto en el que esas acciones han tenido lugar y los intensos diálogos e intertextualidades que su obra mantiene con tantas otras tradiciones (bíblica, dantesca, musical, cinematográfica, etc), el sistema se vuelve todavía más complejo. A la idea expuesta por Ramón Peralta (2006), para quien el paisaje en Zurita se revela como el ejercicio de una lógica poética que logra la síntesis y reconstrucción esencial de la experiencia, entendida como la integración de la tradición literaria del mundo, hemos agregado aquí otras realizaciones del paisaje y otras relaciones entre experiencia y textualidad. También nos ha preocupado analizar cómo se vincula su poesía con diversos espacios de la naturaleza, en líneas relativamente similares a las ya propuestas por Eva Valero (2015), José Carlos Rovira (2011) y Jorge Olcina (2016). Se trataría de una naturaleza que no es telón de fondo, sino una "presencia abrumadora", "en diálogo constante con la cultura" (Rovira cit. por Valero, p.16), una naturaleza que es vista por Olcina como una reserva, que permitirá la resurrección del país. Todo esto en el contexto de una relación con la geografía del país, de larga data, por parte de algunos poetas chilenos. Esta trayectoria mezcla diversas concreciones: actitud de arrobamiento (experiencia de lo sublime frente a la naturaleza); invención con base en lo real; riguroso estudio de estos entornos para su posterior re-creación (Neruda y Mistral, los que más); conciencia mítica y cosmoló- 
gica; despliegue de una poética del habitar; sentido de vulnerabilidad y de horror, provocado por los grandes remezones naturales o políticos.

La obra zuritiana podría inscribirse en esta última tendencia, aunque toma también elementos de todas las anteriores y propone, además, una nueva posibilidad. Creemos que el paisaje es en ella una estrategia para enfrentarse a la historia de la violencia, a la cultura del exterminio y la derrota.

De acuerdo a las distintas funciones que Zurita le asigna al paisaje, se distinguen dos momentos en su obra: uno, que va desde la herida en la mejilla y Purgatorio hasta La vida nueva (LVN) (1994), inclusive; otro, que abarca desde Poemas militantes (2000) hasta Zurita (2011), y que incluye los siguientes libros: INRI (2003), Los países muertos (2006), zurital in memoriam (2008), Cuadernos de guerra (2009) y Las ciudades de agua (2007). Estos momentos, claramente diferenciados entre sí, pueden ser caracterizados como el anverso y reverso de una obra que busca ser leída como una totalidad o un sistema. El primer Zurita construye un discurso donde la sintaxis se encuentra tensionada por la voluntad de decir y de callar al mismo tiempo; el segundo Zurita es más discursivo y narrativo. En el ámbito del tratamiento del paisaje, la diferencia entre estos dos momentos se hace aún más evidente. Si en el primer momento, que va desde Purgatorio a $L V N$, predominan los paisajes pletóricos, delirantes y hasta míticos, alegorizados bajo las imágenes del desierto de Atacama, las cordilleras, los valles, los pastizales o los ríos desbordados, con la clara función de compensar una carencia mental y estructural; en el segundo momento, el paisaje ya no posee esa función compensatoria, y por lo mismo, se vuelve árido, desgastado y prosaico, como se observa con nitidez en Cuadernos de guerra, donde es posible constatar una poética de la devastación.

\section{INICIO Y PROYECCIÓN DE LA OBRA TOTAL:}

\section{LA HERIDA AUTOINFLIGIDA}

El primer texto publicado por Raúl Zurita es Sermón de la montaña (1971), pero su proyecto poético total se inicia con una herida autoinfligida en 1975 con un fierro candente en su mejilla. El poeta había sido víctima, inmediatamente después de ocurrido el Golpe de Estado en Chile, de la tortura, y había estado detenido durante veintiún días en el carguero Maipo junto a otras ochocientas personas, en un lugar donde cabían cincuenta. El registro fotográfico de la herida se transformará, para 1979, en la portada 
de Purgatorio (1979), al que agregará el verso "mi mejilla es el cielo estrellado y los lupanares de Chile" (p. 65), escrito sobre un encefalograma (que simula el estado clínico y material del tratamiento siquiátrico del autor), uniendo ya aquí el cuerpo del país y el del poeta, el cielo y la degradación, bajo el sentido del horror.

Esa quemadura es el inicio de un largo recorrido por el dolor humano y también por cierto "vislumbre de la felicidad" (cf. Serrano, 2000). Dice Zurita sobre esta acción:

Me acababan de botar de una micro por mi aspecto de indigente. Había estado preso en las bodegas del barco Maipo, era comunista, tenía 23 años y cuando me humillaron, me acordé de Jesús diciendo que había que poner la otra mejilla. Era un poeta no publicado, estaba solo y me marqué la cara. Allí empecé a escribir Purgatorio. Y comprendí que no tenía ya que marcar mi cara, sino marcar el cielo y el desierto con una visión que significara, al menos, el vislumbre de la felicidad (p. 24).

La quemadura en la mejilla puede entenderse como un acto que es inscripción y acción a la vez, y que viene a corregir una experiencia marcada por el dolor y corregida por el amor, y desde la cual se trazará un proyecto poético, cuyo eje fundamental será el paisaje. Un paisaje que amanece "gritando" (p. 66) en Anteparaíso (1982) y que a medida que avanza se convertirá en la única posibilidad de nueva vida: "Allá entonces, descendiendo,/ nos nacían los paisajes" ( $L V N, 1994$, p. 45). Pero este paisaje ampliará sus posibilidades de concreción y no será solo representación, a través de la écfrasis, sino que será un recurso, un método para inscribir-escribir los signos del amor y el dolor humanos de otra manera, en otros lugares: desde Purgatorio (1979) hasta Zurita (2011), desde la herida en la mejilla hasta las frases de "Verás" en los acantilados.

La portada de Purgatorio, en su primera edición, consiste en esa foto ampliada, en blanco y negro, de su mejilla quemada, la que a primera vista parece ser más bien un paisaje: la barba de la cara semeja la traza de hierbas o de pastos recortados sobre una especie de pampa o llano. El rostro adquiere, por efecto de la fotografía, la forma de un paisaje y se transforma por ello en prolongación de una obra. Como indica William Rowe (2002), "space is not the setting of the occurrence, but itself occurrence" (p. 283). A partir de allí, el trabajo de Zurita necesitará de una palabra poética que se inscriba más allá de la página (en el rostro, en el cielo, en el suelo, "marcar el cielo y el desierto") y de una nueva geografía que permita escribir de otra manera "el paraíso". Esa herida abre y cierra su proyecto poético. En efecto, 
en su último libro publicado, Tu vida rompiéndose, de 2015, la misma fotografía cierra el volumen, pero ahora bajo un sentido mucho más trágico, más irresoluto y más cruento, según el propio poeta (cf. Miranda, 2016).

\section{DE PURGATORIO A LA VIDA NUEVA: DEL DESIERTO A LOS RÍOS QUE SE AMAN}

En Purgatorio los paisajes en formación -desiertos, pastizales- cumplen la función de sustituir un sentido literal por otro figurado. El desierto de Zurita es lo que resulta de la acción de transponer un conjunto de certezas al plano de la suposición. Eso explicaría el carácter compensatorio de muchas de las ideaciones zuritianas acerca del desierto, que suplantan lo real, como estado no deseable, por un delirio, que compensa una carencia o situación negativa. Estas imágenes delirantes son frecuentemente premisas de las que se desprenden nuevas consecuencias, y sobre las que se efectúan nuevas transposiciones, que van conformando la lógica poética zuritiana. Purgatorio, en cierta forma, es la conformación de esa lógica, la que luego irá desplegándose en los libros sucesivos. Algo muy distinto de lo que había sido el paisaje en la poesía anterior, pues en Zurita no se persigue ni el goce estético ni se busca el disfrute sensorial, más bien él opta por un sublime (inmensidad e infinitud de los entornos) del cual se será víctima o frente al cual se expresará compasión: "para que en toda la patria se escuche ahora el balar de nuestras propias almas sobre esos desolados desiertos miserables" (p. 35).

Por ejemplo, en "los desiertos de Atacama son azules" (p. 34), no hay una desrealización al modo creacionista o surrealista, sino más bien la creación de una premisa a partir de la cual se construye un razonamiento lógico, donde no importa ya el objeto mismo -en este caso, el lugar-, sino la función que este va a desempeñar dentro del sistema poético. En este caso, el desierto es calificado con una cualidad propia del cielo. Aquí tenemos el principio de una operación metafórica, pero a nivel de la estructura. El paso siguiente habría sido decir: el desierto es el cielo. En el cielo hay nubes. Las nubes parecen ovejas. En el desierto hay ovejas. Las ovejas balan. Entonces se puede escuchar nuestras propias almas balando en el desierto. Pero luego se realiza una operación compensatoria, al equilibrar la escena propuesta con imágenes que desafían la lógica geográfica, "Miren a esas ovejas correr sobre los pastizales del desierto" (p. 35). Pues lo "que representa el desierto es en realidad lo que se ha perdido, o el signo impulsivo de 
la irreparable pérdida" (Jacobo, 2016, p. 231). Una forma de recuperación de esa pérdida será un desierto con pastizales y con ovejas corriendo a través de él. Un desierto azul.

Purgatorio es también un espacio de sobrevivencia poética, áreas de respiro para un sujeto roto y confinado en un baño ("Domingo en la mañana") o en el retiro de su propio estado sicológico. Los paisajes construidos por este sujeto compensan algunas de sus privaciones: pensamos en el "infinito del desierto de Atacama”, que se opone a los estrechos límites de su confinación (física y mental). Esta posibilidad de libertad, implícita en la imagen del Desierto de Atacama, contrasta con esa otra imagen del sujeto encerrado en un baño, vestido de harapos de lana gris. Esta operación o función podría codificarse también en términos bíblicos, como la relación entre caída y ascensión.

En Anteparaíso, en cambio, el desierto cede su lugar pleno a los pastizales ("Pastoral de Chile"), como un espacio en que es posible una reparación, la sutura de una herida. La mejilla inmolada del autor de Purgatorio se proyecta ahora en las frases escritas en el cielo de Nueva York ${ }^{1}$, lugar donde el dolor construye una función reparadora. La escritura en el cielo y su correspondiente fotografía, suponen la voluntad de materializar un deseo colectivo, una utopía, o bien la corrección de una carencia. A través del recurso anafórico, esa carencia -el hambre de dios- se vuelve visible, obsesiva en la constante reiteración o en la tautología: "MI DIOS ES MI AMOR DE DIOS" (pp. 64-67).

Así, el desierto, que en Purgatorio funcionaba como una prolongación textual de una experiencia en crisis, en Anteparaíso cumple la función de reconciliación amorosa de la patria con los hijos ("Las playas de Chile") y de reencuentro entre lo individual y lo colectivo, para recuperar un país distinto del degradado por los militares. La violencia física y discursiva ejercida por estos militares se manifiesta en distintos elementos de las morfologías naturales chilenas, muchas de las cuales son abordadas como paisaje: "Amanecían gritando estos paisajes" (p. 66). Zurita paisajiza así el país, para oponerse a su devastadora militarización. Para Jorge Olcina (2016) quien distingue aquí "tres estadios, no obligatoriamente cronológicos, en la consideración de la geografía chilena" (p. 351), este momento sería el despertar de un "sentimiento de 'renacimiento' como escenario de regene-

\footnotetext{
${ }^{1}$ Iconotextos incluidos en Anteparaíso y que registran los quince versos trazados con humo en los cielos de Quenns en 1982, en un proyecto diseñado por el propio poeta y cuya lectura efímera solo se pudo realizar desde la tierra del capitalismo, por breves momentos. Una muy lúcida aproximación a estos iconotextos es la realizada por Jorge Lagos (2010), quien los estudia como recursos transtextuales.
} 
ración" (p. 354), donde la "naturaleza se presenta como reserva de valores en 'Pastoral de Chile' (Anteparaíso); y se reivindica como metáfora de la necesidad vital de resurgir del pueblo chileno” (p. 354).

Esta idea de un país-paisaje como pasión colectiva se proyectará con más fuerza en Canto a su amor desaparecido (1985), donde los desiertos son "desiertos de amor" y donde el amor de los detenidos desaparecidos quedará pegado a las rocas, el mar y las montañas, en un acto de supervivencia colectiva, donde se opone la inmanencia amorosa a la tradicional trascendencia, como forma de sobrevivir a la muerte. La función fundamental de los paisajes será aquí evitar que los sueños mueran, pese a las escenificaciones negativas de los mismos. La necrópolis de Canto a su amor..., tan bien estudiada por Edmundo Garrido (2008), será el lugar privilegiado. La desaparición de los países es compensada fuertemente por la heterotopía del cementerio. El único espacio que distiende en parte esta hegemonía de la muerte es la imagen del desierto: "desiertos de amor". El desierto tenía ya en Purgatorio la connotación positiva de patria. En Canto a su amor... el desierto no es un lugar geográfico, sino geométrico, como indica Waldo Rojas (2004), que re-semantiza a los propios sujetos que habitan en él, bajo el signo de la desertitud, en una operación donde se asimila el paisaje desértico a la rostridad. En Canto a su amor... entonces, el paisaje es un método que permite descomponer el país y las morfologías naturales del país, para proclamar una única salvación: aquella simbolizada por la eternidad del canto, la permanencia de la naturaleza y del amor adherido a ella ${ }^{2}$.

Será en $L V N$ donde Zurita logre darle un nuevo giro a algunas búsquedas de la primera etapa de su obra: su relación con el canto y la escritura; el modelo mítico y la relación no paisajística con la naturaleza chilena. Todo influido, de manera determinante, por su encuentro con la cultura mapuche y con la poesía de Leonel Lienlaf y de Elicura Chihuailaf. Hasta antes de $L V N$, los paisajes de Zurita eran culturizados y se esgrimían bajo imágenes de lo hórrido: por eso la preeminencia del purgatorio, el nicho y el desierto. Ya ahí se creía que la meta era la creación de un paraíso en la tierra. Recuérdese que pairidaeza es originalmente, en persa antiguo, un cercado, es

\footnotetext{
${ }^{2}$ Aquí no podríamos hacernos cargo de una dimensión más potente todavía de su proyecto poético encarnado en Canto a su amor desaparecido, y que dice relación con la forma en que el poema porta una fuerza pragmática, que va más allá del libro y del autor. Recordemos que el verso "Todo mi amor está aquí y se ha quedado pegado a las rocas, al mar y a las montañas" se encuentra hoy petro-grabado, encabezando el Memorial del Detenido Desaparecido y del Ejecutado Político, erigido en el patio 102 del Cementerio General de Santiago de Chile. El nombre del poeta fue borrado como autor y la frase le pertenece ahora a todas las víctimas del horror y a sus deudos.
} 
decir, un lugar rodeado por murallas, un jardín resguardado de amenazas y desborde. Acá en cambio, en $L V N$, lo que prima es el desborde, las imágenes genésicas y sobre todo escatológicas: ríos de que se arrojan (y que se aman, siguiendo a Lienlaf) las primeras migraciones, torrentes que desbordan los Andes, océanos que a través de glaciaciones destruyen y reconstruyen el mundo, además de ascender al aire. Es interesante observar cómo en medio de estas imágenes repetitivas y mántricas, son restituidos, gracias a la fuerza de la naturaleza, los países muertos (los nichos) de su Canto a su amor desaparecido, el que está parcialmente intertextualizado aquí.

Para fortalecer su nueva relación con el paisaje, el poeta recupera antiguos mitos y memorias del origen de diversas culturas, incluida la bíblica, especialmente de América Latina, esos "mitos en los que fuimos tejidos" (Tu vida, 2015, p. 302). Fuerza elemental fundamental de estos ciclos de destrucción y regeneración son aquí las aguas. Aguas que son aquí ríos que se aman y aman, que dan origen al mundo y a la circulación de la vida (arrojo), pero que también destruyen y provocan mortandad. Son ríos concretos como el Yelcho, el Michimahuida o el Futalelfú, los que parecen acentuar el carácter localista de la memoria mítica. De hecho, Zurita mapeó rigurosamente muchos de los lugares reales aquí poetizados, antes de escribirlos. Interesante resulta, además, que los grandes accidentes geográficos y las morfologías naturales que adquieren aquí fisonomías más territoriales y mucho más concretas, estén siempre mediadas por la mirada y el testimonio de otros, que también son personas muy concretas, en casi todos los casos. Creemos que esto aminora el carácter alegórico de su poesía e incrementa su intención de acercarse lo más posible a lo real. La relación con la naturaleza ahora, en $L V N$, se aleja definitivamente de las nociones modernas de país y paisaje, y se da en clave de una función muy concreta, de "espacio vivido" (Soja, 1997), de memoria geológica y humana.

\section{DE INRI A ZURITA: PALIMPSESTOS Y RADICALIDAD DEL REFERENTE}

En esta etapa ha cambiado la manera de concebir la relación entre poesía, país y paisaje, pues está ahora la voluntad de borrar un hecho de la experiencia, un fragmento de la vida colectiva de Chile, a través de la corrección de su propia obra. En esta segunda etapa, el referente real se hace sentir con mucha más determinación. En INRI (2003), por ejemplo, la fuerza del contexto se manifiesta a través del impacto que causará en el poeta la publi- 
cación de los informes sobre violación a los derechos humanos en tiempos de dictadura ${ }^{3}$. En este segundo momento, el lenguaje tiende a lo prosaico, a lo antilírico, a través de la puesta en práctica de la sátira y la parodia, las que incorporan un humor corrosivo y carnavalesco, ausente en su etapa anterior, excepción hecha de algunos poemas como "Desierto de Atacama" de Purgatorio o "Allá lejos" de Anteparaíso. Volveremos sobre esto, a propósito de Los países muertos.

El peso del referente y la radicalidad de la función-paisaje se evidencia fuertemente en INRI, además de criticar, a través de la intertextualidad, el Himno Nacional de Chile. En la sección "El mar" (pp. 17-27) se nos muestra una escena de enorme crudeza: cuerpos humanos son arrojados desde el cielo sobre el mar, como carnadas para los peces. El mar es carnívoro y los peces son las tumbas del cielo. Esta escena de permanente movimiento es descrita por un observador testigo que solo puede oír, pero no ver, evidencia de un correlato histórico: la forma en que fueron hechos desaparecer los cuerpos de cientos de detenidos durante la dictadura militar en Chile, con sus vistas vendadas con capuchas o bien, la extirpación de los ojos de algunos de ellos. La imagen descrita se va complejizando en progresión: si los cuerpos caen desde el cielo, en su caída se llevan pedazos de cielo adentro; los peces al devorarlos se transforman en las tumbas del cielo. Las carnadas son cristos que caen en las cruces del mar, escenificando un acto sacrificial, que hacia el final del poema se resuelve en una redención: los peces ascienden al cielo, restituyendo las carnadas, con pedazos de cielo adentro, a su lugar de origen.

En la sección "Flores" (pp. 91-101) se nos presenta la desaparición de una parte fundamental del territorio de Chile: el Océano Pacífico y la Cordillera de los Andes, desde cuyos espacios surgen las flores. Esta escena, que trae reminiscencias del jardín terrenal, del paraíso en la tierra, también se presenta como un enorme cementerio lleno de flores, un camposanto ("Chile es un camposanto" p. 96). Se habla aquí de la desaparición del paisaje asimilable a Chile, como país y como proyección de un imaginario territorial: Océano Pacífico, Cordillera de los Andes y Valle Central, y del surgimiento de un nuevo paisaje, compuesto por magnolias blancas, que ocupan el lugar de las cordilleras, y hortensias azules, que ocupan el lugar del mar. Aquí también, como en el poema "El Mar", se observa un movi-

\footnotetext{
${ }^{3}$ Especialmente el Informe de la Comisión Nacional de Verdad y Reconciliación (Informe Rettig) de 1990 y el Informe de la Comisión Nacional sobre Prisión Política y Tortura (Informe Valech) de 2003-2011.
} 
miento de restitución de la vida a partir de la muerte, a través de la proliferación de las flores y su crecimiento desde las cuencas vacías de los ojos de los muertos. Lo que muere es un territorio -cordilleras, Océano- y lo que surge es el paisaje entendido como el vínculo afectivo entre un lugar y un sujeto que lo contempla. El país se representa como un cementerio y un extenso jardín, es decir, naturaleza dispuesta estéticamente, "un campo de flores bordado"-"la copia feliz del Edén" del Himno Nacional-, tópico o lugar común que resulta parodiado.

Pero será Los países muertos (2006) el libro que marca una importante inflexión en este segundo momento, pues él abre a nuestro juicio una nueva etapa en su poesía en el ámbito del significante. El lenguaje se vuelve narrativo y el verso como unidad de ritmo o sentido cede a la linealidad del discurso. Creemos que también el humor alcanza su máxima caracterización y definición aquí: el autor aborda satíricamente la escena literaria de su época, en la forma de un ajusticiamiento público o de un contrahomenaje o anti-memorial. Se acentúa aquí un humor carnavalesco, cuyos antecedentes podrían rastrearse en el poema "Allá lejos" (p. 54), de Anteparaíso, donde se someten a reelaboración paródica los textos "Carretera 61" y "Sueño 115" de Bob Dylan (2016). Cercanos a la sátira y al humor negro, estos poemas establecen un contrapunto a las construcciones pletóricas de algunos de sus libros anteriores.

La abundancia fluvial de $L V N$, ligada al relato escatológico y genésico, cede su lugar, en Los países muertos, a un paisaje que funciona como el sustituto de la tierra prometida: un país devastado, destruido, donde el mar se abre dejando pasar un nuevo estrecho: "mi corazón es el país más devastado" (Los países muertos, p. 65), donde Zurita cita a Ungaretti. Proyectados sobre este paisaje, aparecen personajes esperpénticos -títeres "culeados" (p. 14)-, que representan personas reales de la contingencia cultural chilena: escritores, poetas, críticos, etc. Esto parecería contener la crítica al arte en la era posmoderna, que Zurita realizará con mayor radicalidad en su siguiente libro: zurita/in memoriam (2007); cuando frente al acto de unos fotógrafos alemanes de intervenir con color rosado las fotografías de unos ejecutados en el cauce del río Mapocho, el poeta exclama: "joder con los artistas" (in mem, p. 12). Cada uno de los personajes de Los países muertos está caracterizado por un epíteto o un calificativo, la mayor parte de las veces, peyorativo o caricaturesco, siguiendo el modelo del infierno de Dante en La Divina Comedia.

En la primera parte del libro, los poemas siguen el siguiente formato: 1. Aparecen los personajes "contingentes" con su epíteto, sometidos 
a un tratamiento carnavalesco; 2. Aparece el paisaje: la cordillera que gira sobre sí misma, las playas que se elevan como terraplenes, el mar que se abre, el cielo que cae, las aguas que se abren como nalgas, dando lugar a un acto de violación. Zurita, aquí, pareciera oponer la grandeza de las fuerzas naturales a la fugacidad y pequeñez caricaturesca de la humanidad, representada por estos personajes públicos del quehacer cultural chileno, aparentemente investidos de un prestigio o una dignidad que se vuelve ridícula frente a la grandeza del océano y de las cordilleras. La imagen de mayor violencia es la del estrecho, que se abre atravesando el mar, partido en dos, como el ano de un trasero enorme. Si en Purgatorio Zurita situaba el Desierto de Atacama en la mente -"Mi propia mente el desierto de Chile" (1979, p. 25)- en Los países muertos será el corazón el lugar donde habite ese otro desierto aún más devastado, ese que Zurita designa con el nombre de país: "Mi corazón es el país más devastado" (2006, p. 25). Así, persona y territorio se identifican en el corazón, que es el lugar común por antonomasia de la pasión humana. Justamente de ese vínculo nacerá el paisaje, como el afecto ligado a los lugares.

En Zurita (2011), penúltimo libro del autor, se reescriben casi todos los libros de esta segunda etapa y también algunos de la primera. Este libro toma como método compositivo la reescritura. En base a ella se engarzan los libros anteriores en torno a una suerte de relato autobiográfico que es intervenido de acuerdo a una planificación, que da cuenta de lo que ocurre la noche anterior al golpe militar, la noche misma y el amanecer del día siguiente ("TU ROTA TARDE", “TU ROTA NOCHE", "TU ROTO AMANECER", respectivamente). Dentro de este trabajo de reescritura, es fundamental el ensamblaje de numerosos fragmentos de su novela autobiográfica En el día más blanco (1999), los que al disponerse en un orden distinto al original adquieren una nueva funcionalidad al interior del libro. Esta funcionalidad podría definirse como la voluntad de resignificar una obra que, desde un principio, se planteó en relación sistémica con la propia vida del autor. Dicha resignificación pone de relieve lo que Zurita tiene de obra total, entendiendo por tal, una obra que delata el arte poética que la sustenta, además del arte vital que le sirve de fundamento, pues está concebida como un texto, susceptible de ser reescrito y corregido.

La inserción al inicio del libro de uno de sus primeros textos metapoéticos, "Qué es el paraíso", de 1979, es sumamente relevante en este sentido: "trabajar con la vida es trabajar con la corrección sistemática de la propia experiencia asumida como un borrador de la experiencia que será, de la vida que alguna vez será (...) Entonces el trabajo en la obra del Paraíso no 
es sólo un trabajo de arte sino de corrección del dolor de la experiencia" (2015, p. 14). En dicho texto se plantea la necesidad de concebir la vida como una obra incompleta e imperfecta que el arte debe corregir, y a la vez pensar el arte como la construcción de la obra del Paraíso, entendido como una práctica que desde el dolor, es decir, desde el hambre, transforme la experiencia del dolor en la construcción colectiva de un nuevo significado. Esto se constata no solo en las diferentes versiones de un mismo texto, como en el caso de "Domingo en la mañana" (p. 15) de Purgatorio, sino también en las modificaciones de textos anteriores a Zurita, y que fueron incluidos en él, con numerosas variantes.

Luego del texto programático, se sigue con las fotografías de un proyecto: la intervención en la costa norte de Chile, en sus acantilados, de frases que comienzan con "Verás". Es decir, lo que antecede a Zurita es una poética y un proyecto: la construcción del Paraíso, como la propia experiencia que se proyecta desde la obra hacia el exterior, a través de la escritura sobre los acantilados de la costa norte de Chile, realizada por el momento en veintidós fotografías a gran tamaño intervenidas con frases manuscritas del poeta. Es entonces cuando Zurita concreta su mirada del paisaje, como una función y un método de intervención de la propia experiencia. Estas veintidós frases son citas intervenidas de la propia obra del autor, inscritas en un espacio físico que excede los límites de la literatura, para configurar la mirada de un paisaje, hecho de los retazos de una obra: "Verás un mar de piedras; Verás margaritas en el mar; Verás un dios de hambre; Verás el hambre, Verás un país de sed (...) Verás ciudades de agua; Verás cielos en fuga; Verás que se va; Verás no ver y llorarás" (2011, pp. 719-40). Esas afirmaciones enunciadas en futuro, proyectadas hacia un tiempo que será, casi como una imposición, surgen desde la propia obra anterior de Zurita. Por ejemplo: "Verás un dios de hambre", reformula el "Mi dios es hambre" de Anteparaíso, y "Verás ciudades de agua", retoma el título de Las ciudades de agua. Retazos que forman parte de una obra que se cita a sí misma, pero transformándose en otra cosa. Así, el paisaje en Zurita es también la proyección de su propia poética.

Zurita funciona como el reverso de $L V N$, de hecho, su color negro (tapa y contratapa), contrasta antitéticamente con el blanco total de $L V N$. Además, si en $L V N$ todo tiende a la convergencia, en Zurita tiende a la divergencia, a lo que se rompe. En lugar de la circularidad mítica y analógica de $L V N$, predomina aquí la historia, la fisura, el quiebre, la ironía. Frente al verdor de $L V N$, prevalece la aridez de Zurita. Aquí el paisaje se construye a partir de fragmentos, retazos de un país desecho, de un territorio devas- 
tado, donde el mar ha desaparecido y en su lugar hay piedras, donde los acantilados cortan a pique cualquier posibilidad de continuidad o redención. Pareciera que el país utilizara el paisaje para intervenir en su propia conciencia y autoimagen: ambas devastadas. En la página veintidós se lee: "Costa norte, acantilados: Pero no fue el Paraíso, Little boy, sino sólo el reseco desierto donde hace millones de años estuvo el Pacífico y al frente unas frases de amor, de locura y de muerte, escritas en los acantilados atravesando la rota tarde, la noche rota, tu desolado amanecer" (2011, p. 22). Sus frases son una prolongación de la escritura sobre los cielos de Nueva York (1982) y también de su verso escrito en el Desierto de Atacama (1993). Como si el autor contemplara, ya en una era poshumana, sus propias frases sobre la geografía y las apreciara en su real precariedad, prosaísmo y desencanto quiroguiano. Este párrafo con que se abre Zurita cancela cualquier pretensión redencionista, cualquier aspiración trascendente o utópica, que pueda proyectarse sobre el paisaje. Zurita se suma así a los artistas que en los años 60 inauguran una nueva relación social con el paisaje: el de la artealizacion in situ (Roger, 2007), en la que se agrega desde el arte y de una forma material, algo nuevo al paisaje. Es el caso de los dibujos en el cielo de Openheimm o de las intervenciones en el desierto de Nevada de Michael Heizer, con los cuales Juan Soros (2012) ha comparado la obra de Zurita. La diferencia en Zurita es que en él sigue primando la palabra inscrita y la urgencia de dejar su testimonio y que estas intervenciones integran también su proyecto poético.

La escritura en el cielo de Queens y su correspondiente fotografía suponía la voluntad de materializar una utopía colectiva, a través del recurso anafórico. Esa carencia -el hambre de dios- se volvía visible, obsesivo y tautológico: "MI DIOS ES MI AMOR DE DIOS", según ya lo explicamos. Estos astroglifos, visibles momentáneamente por algunas horas desde el suelo, se transformarán en 1993 en gigantescos geoglifos en el Desierto de Atacama, ahora solo visibles desde el cielo o desde lo alto. En efecto, ya terminada la dictadura, Zurita realizó la escritura monumental con máquinas retroexcavadoras de la frase manuscrita "ni pena ni miedo". De carácter más bien permanente, su extensión total es de $3 \mathrm{~km}$. Cada letra mide $250 \mathrm{~m}$ y el espacio al interior de las letras es de $40 \mathrm{~m}$ de ancho con una profundidad en declive de 1,80 m. El verso se puede leer desde distintos miradores cercanos, pero es más visible en su totalidad a cierta altura desde el cielo o desde satélites. El verso es una frase-promesa (palabra-acción) que parafrasea, con menos radicalidad, la consigna "ni perdón ni olvido" de las agrupaciones de Derechos Humanos como una exigencia de justicia por los 
ejecutados, torturados y desaparecidos en Chile. Se trataría pues del deseo de vivir al menos sin pena y sin miedo, aunque nos sea negada la justicia e incluso la memoria. Tanto en el cielo como en el desierto, lugares utópicos por excelencia, quedarán estos mensajes para el futuro, en donde la humanidad ya no existirá como tal. Con su "ni pena ni miedo", Zurita cierra también su propia herida en su rostro, cuyo color él mismo ha asimilado con el color del desierto: en lugar de la herida (que el tiempo se encargará también de borrar) lo que permanecerá será el desierto interpelándonos. De hecho, el libro Zurita se cierra con la fotografía del desierto sin la frase, iconotexto intervenido de la fotografía que años antes fuese tomada desde el aire por un avión de la FACH y de la que ahora ha sido borrada la frase "ni pena ni miedo". En este desierto asociado a lo no humano o bien a la imagen del peregrinaje o a la búsqueda de la santidad, Zurita ha escogido dejar su mensaje de nueva inscripción de "Vida Nueva". En estas morfologías, donde antiguamente los sabios leían signos para mejor vivir, el poeta deja su mensaje para un mundo poshumano, y también su borradura. Lo que le da contenido a su proyecto es la propuesta de la inscripción de un nuevo sentido de paisaje en el propio cuerpo y en el del país: por eso las cuencas de los ojos son las cuencas del océano Pacífico y la mejilla es el desierto de Atacama, lugar donde ha elegido dejarnos su mensaje más permanente e indeleble: su verso "ni pena ni miedo".

\section{REFERENCIAS}

Ansón, A. (2008). Territorios y paisajes. Modelos para pensar fotografía y literatura, tal vez soñar. En: Maderuelo, J. (ed.) Paisaje y territorio (pp. 227254). Madrid: Abada Editores.

Comisión Nacional de Verdad y Reconciliación (1990). Informe de la Comisión Nacional de Verdad y Reconciliación (Informe Rettig). Santiago, Chile.

Comisión Nacional sobre Prisión Política y Tortura (2012). Informe de la Comisión Nacional sobre Prisión Política y Tortura (Informe Valech) de 20032011. Santiago, Chile.

Dylan, B. (2016). Letras completas. Barcelona: Malpaso Ediciones.

Garrido, E. (2008). Construir una ciudad para la memoria: Canto a su amor desaparecido de Raúl Zurita. Revista de Filología Románica, VI, 161-171.

Jacobo, A. (2016). Hacia una poética del espacio de la naturaleza: la proyección espacial dinámica/estática del paisaje en Purgatorio y Anteparaíso. En: Alemany, Carmen et al. (eds.). Raúl Zurita. Alegoría de la desolación y la esperanza (pp. 225-238). Madrid: Visor Libros/Universidad de Alicante.

Lagos, J. (2010). Retórica de la imagen en Anteparaíso de Raúl Zurita. Estudios Filológicos, 45, 49-55. 
Miranda, P. (2016, 6 de enero). Entrevista a Raúl Zurita. Inédita.

Olcina, J. (2016). Aguas, montañas y cielos en la obra de Raúl Zurita. En: Alemany, C. et al. (eds.). Raúl Zurita. Alegoría de la desolación y la esperanza (pp. 337-359). Madrid: Visor Libros/Universidad de Alicante.

Peralta, R. (2006). El paisaje en la obra de Raúl Zurita. Letras s5. Recuperado de http://www.letras.s5.com/rz151106.htm

Roger, A. (2007). Naturaleza y cultura. La doble artealización. En Roger, A. Breve tratado del paisaje (pp. 15-36). Madrid: Biblioteca Nueva.

Rojas, R. (ed.) (2015). Raúl Zurita. Escritura material. Santiago: Escuela de Arte Universidad Diego Portales.

Rojas, W. (2004). Raúl Zurita: ¿a las puertas de la esquizopóiesis? Proyecto Patrimonio. Recuperado de http://www.letras.mysite.com/rz060404.htm

Rovira, J. C. (2011). Zurita, obra en progreso. En: Alonso, M.N y Alemany, C. (eds.). Diálogos para el bicentenario (pp. 81-103). Concepción: Editorial Universidad de Concepción.

Rowe, W. (2002). Poets of contemporary Latin America: history and the inner life. Oxford: Oxford University Press.

Serrano, M. (3 de septiembre de 2000). Entrevista a Raúl Zurita. He sido honesto con lo que he hecho. La Tercera, 24-25. Recuperado de http://www. bibliotecanacionaldigital.cl/bnd/628/w3-article-353443.html

Soja, E. (1997). El tercer espacio. Ampliando el horizonte de la imaginación geográfica. Revista Geographikós, 71-76.

Soros, J. (2012). Blurring the boundaries between land art and poetry in the work of Raúl Zurita. Review: Literature and Arts of theAmericas, 45.2, octubre, 227-235.

Valero, E. (2015). Enteras de agua, las ciudades: una nueva poética urbana en Zurita. Atenea, 511, 15-31.

. (2016). Ciudades borradas: ver y oír (sentir) la poética urbana de Raúl Zurita. En: Alemany, Carmen et al. (eds.). Raúl Zurita. Alegoría de la desolación y la esperanza (pp. 457-490). Madrid: Visor Libros/Universidad de Alicante.

Zurita, R. (1979). Purgatorio. Santiago: Universitaria. - (1982). Anteparaíso. Santiago: Editores Asociados.

. (1985). Canto a su amor desaparecido. Santiago: Universitaria.

(1994). La vida nueva. Santiago: Universitaria. (1999). El día más blanco. Santiago: Alfaguara.

. (2000). Poemas militantes. Santiago: Dolmen Ediciones.

. (2003). INRI. Ciudad de México: Fondo de Cultura Económica.

. (2006). Los países muertos. Santiago: Ediciones Tácitas.

. (2008). in memoriam/ zurita. Santiago: Ediciones Tácitas.

. (2009). Cuadernos de guerra. Santiago: Ediciones Tácitas.

(2011). Zurita. Santiago: Ediciones UDP.

. (2015). Tu vida rompiéndose. Santiago: Lumen/Ramdom House Grupo

Editorial. 